\title{
ROLA PRZEDSTAWIEŃ DRZEWA GENEALOGICZNEGO ZAKONU W ŚRODOWISKU PREMONSTRATENSÓW
}

Powszechnie znane przedstawienie Drzewa Jessego, zainspirowane słowami z Księgi Izajasza: „I wyjdzie różdżka z korzenia Jessego i kwiat z korzenia jego wyrośnie” (Iz 11,1), informuje „o historycznych i ludzkich powiązaniach Jezusa” oraz obrazuje jego ,pozycję w społeczeństwie tamtych czasów, wskazując na Dawida i tym samym na mesjańskość"1 (il. 1). W sztuce już od najdawniejszych czasów, jak wykazał Arthur Watson, wzbogacano to wyobrażenie opierając na innych tekstach prorockich ${ }^{2}$. W okresie dojrzałego baroku przeżywało popularność w szczególnym typie ikonograficznym Arbor Virginis $^{3}$ (il. 2), jako ,jeden z elementów gloryfikacji Panny Marii"'4. W przedstawieniu tym z ogromnej grupy, bo sięgającej 56 osób, ,przodków Matki Bożej pozostają jedynie postaci jej rodziców, a drzewo - to już tylko dwie gałęzie lub raczej łodygi, wyrastające z piersi św. Anny i Joachima i łącząc się ze sobą, tworzą kwiat, na którym stoi Niepokalana"s.

\footnotetext{
* Lidia Kwiatkowska-Frejlich - dr historii sztuki, adiunkt w Instytucie Kulturoznawstwa UMCS. 40.

${ }^{1}$ J. Ratzinger, Córa Syjonu. Maryja w refleksji Kościoła, tłum. B. Widła, Warszawa 1997, s. 32,

${ }^{2}$ Arthur Watson zamieszcza listę tych proroctw, zob. Tenże, The Early Iconography of the Tree of Jesse, Oxford 1934, s. 151 i nn.; J.R. Johnson, The Tree of Jesse Window of Charters: LAUDES REGIAE, „Speculum: a journal of medieval studies”, 36 (1961) nr 1; M.D. Taylor, The Prophetic Scenes in the Tree of Jesse at Orvieto, „The Art Bulletin”, 54 (1972).

${ }^{3}$ M. Biernacka, Niepokalane Poczęcie, w: Maryja Matka Chrystusa, red. M. Biernacka i in., Warszawa 1987, s. 39-40.

${ }^{4}$ T. Chrzanowski, Sztuka w Polsce od I do III Rzeczypospolitej, Warszawa 1998, s. 194. Jan Samek twierdził, że przemawia za tym fakt, że „obrona tezy o Niepokalanym Poczęciu była jednym z ważkich problemów w życiu religijnym w Polsce wieku siedemnastego", tenże, Problem aktualności tematu „Drzewo Jessego” w sztuce polskiej wieku siedemnastego, „Zeszyty Naukowe Uniwersytetu Jagiellońskiego” t. 339, „Prace z Historii Sztuki”, 11 (1973) s. 57.

${ }^{5}$ Tamże, s. 39-40. O popularności tego motywu ikonograficznego w sztuce polskiej od czasu romanizmu zob. Samek, Problem aktualności tematu „,Drzewo Jessego”, s. 55.
} 
Motyw plastyczny ukazujący konary wyrastające z piersi rodziców i rozgałęziające się z postaciami potomków, obrazuje przede wszystkim fakt pochodzenia ${ }^{6}$. Jak żaden inny był odpowiedni, by wskazać ścisłe zależności wynikające z następstwa pokoleń w rodzinie. Od dwunastego wieku przejęła go sztuka świecka ${ }^{7}$. W zamku w Brzegu znajdujemy polichromowane przedstawienie Drzewa genealogicznego Jerzego II (il. 3). Innym przykładem parafrazowania Drzewa Jessego jest rycina, wydana w Szczecinie w 1618 r.: Drzewo genealogiczne herezji (il. 4): „u dołu wyobrażony został leżący mężczyzna w żydowskim stroju, podpisany jako «FARISAISMUS», wspierający się na liściu z inskrypcją «SIMON MAGNUS». Z jego ust wydobywa się snop ognia z bazyliszkiem i wężem. Wyrastające, owinięte wyobrażeniem węża i splecione ze sobą dwa pnie zostały określone jako «Papizm» i «Mahometanismus», zaś liczne gałęzie i liście opatrzone zostały nazwami identyfikującymi «pokrewne sobie» herezje" "

Popularne były również przedstawienia zakonnego drzewa genealogicznego, a pierwsze polskie Jan Samek datuje na pocz. XVI wieku ${ }^{10}$. Wczesnym przykładem jest bardzo ciekawy obraz z 1608 r. zatytułowany: Barokowe drzewo genealogiczne rodziny de Guzmanów i zakonne dominikanów i dominikanek w kościele Bożego Ciała w Krakowie (il. 5). W przedstawieniach takich widzimy jedynie osoby konsekrowane, podstawę kompozycji stanowi postać twórcy reguły, a wyrastające $\mathrm{z}$ niego drzewo unosi na gałęziach najznakomitszych przedstawicieli zakonu. Taki obraz znajdujemy w klasztorze paulinów na Skałce, na którym ukazano św. Pawła jako praojca anachoretów. Również w dawnym kościele benedyktynek w Sandomierzu powstało w latach 1694-1695, tym razem snycerskie, drzewo genealogiczne zakonu (il. 6). W tych przedstawieniach układ kompozycyjny jest podobny: założyciele zakonu przedstawiani zostali w pozycji leżącej, a oczy mają zamknięte. $Z$ ich ciała wyrasta jedna, najwyżej dwie gałęzie, na których widnieją półpostacie lub tylko imiona świętych. W przypadku zakonnego drzewa genealogicznego nie możemy mówić o wyobrażeniu pochodzenia rodzinnego wynikającego z krwi. Jaką zatem ideę ma na celu zobrazować taki obraz?

$\mathrm{Na}$ to pytanie możemy próbować odpowiedzieć analizując obraz Drzewo genealogiczne św. Brygidy (il. 7) w byłym kościele brygidek w Lublinie. Mamy tu do czynienia z przedstawieniem o innym rozwiązaniu formalnym, gdyż z ciała zakonodawczyni, św. Brygidy, klęczącej frontalnie, wyprowadzono nie tylko siostry i braci zakonu Najświętszego Zbawiciela, ale również jej naturalne dzieci. Postać świętej w obrazie przybrała formę pnia rozsiadłego na wzgórzu. Łodygi, które wyrastają z jej ciała zakończone są pojedynczym kwiatem lilii, a w każdym z nich widzimy półpostać i napis, który ją identyfikuje. Są to imiona synów i córek św.

${ }^{6}$ Biernacka, Niepokalane Poczęcie, s. 39-40.

${ }^{7}$ G.B. Ladner, Medieval and Modern Understanding of symbolism: a Comparision, „Speculum: a journal of medieval studies", 54 (1979) nr 2, s. 249.

${ }^{8}$ Wykonane przez malarza nadwornego księcia Jerzego II Baltazara Latoniusa w latach 1583 1584. Portret na Ślasku XVI-XVIII, red. E. Houszka, Wrocław 1984, s. 12 (katalog wystawy).

${ }^{9}$ M. Wisłocki, Treści polemiczne w ewangelickiej sztuce Pomorza XVI i XVII wieku, w: Sztuka i dialog wyznań w XVI i XVII wieku, red. J. Harasimowicz, Warszawa 2000, s. 151.

${ }^{10}$ Samek, Problem aktualności tematu „Drzewo Jessego”, s. 57-58. 
Brygidy. W najwyżej ulokowanych dwóch kwiatach, zgrupowani zostali zakonnice i zakonnicy brygidiańscy, znajdują się na wysokości wieńczących kompozycję Maryi i Dzieciątka. Dzieci świętej ukazane są każde z osobna, jakby w ten sposób autor chciał unaocznić fakt, że sama je urodziła. Zakonnicy również jednym aktem założycielskim zakonu stali się dziećmi świętej. Jest to zobrazowanie słów Chrystusa skierowanych do niej po tym, gdy zdecydowała, że będzie żyć ,jak zakonnica" ${ }^{11}$. Będąc w zachwyceniu mistycznym usłyszała od Jezusa, że gdy będzie zachowywała jego wolę, żyła zachowując milczenie, skromność ubioru i nigdy nie wyjdzie ponownie za mąż, „to wtedy w przyszłości będziesz matką dla dzieci duchowych, podobnie jak teraz jesteś matką dla dzieci w porządku naturalnym"12. Możemy więc wnosić, że przedstawienie drzewa genealogicznego zakonu obrazuje fakt „wyprowadzenia” z zakonodawcy - który sformułował regułę zakonu - jego dzieci duchowych, tak jak własnych dzieci w porządku naturalnym.

Obraz, który mnie tu najbardziej interesuje, przechowywany w konwencie w Imbramowicach (il. 8), pochodzi z XVIII wieku ${ }^{13}$. Ukazuje na neutralnym tle drzewo genealogiczne premonstratensów. Jedynie na dole kompozycji, a tuż obok, gdzie na zielonym wzgórzu leży św. Norbert, widzimy sylwetkę bezwieżowego kościoła otoczonego wysokim murem z okrągłą basztą. Święty w lewej ręce trzyma palmę, a z okolic jego serca wyrasta drzewo, które jest elementem organizującym całą kompozycję: szerokim pniem przebiega przez środek sceny. Wyrastające z niego konary są podstawą różowych kwiatów, na których ulokowani są święci norbertańscy. Drzewo to wieńczy postać Ukrzyżowanego Chrystusa na tle jaśniejącej mandorli. Chociaż nie ma tu krzyża, to jego ciało zostało uformowane tak jakby było do niego przybite: stopami złożonymi jedna na drugą, dotyka wierzchołka pnia, a ręce ma szeroko rozłożone. Dłońmi chwyta dwa zielone, bujnie pędy. W sztuce tego zakonu już od czasów romanizmu zauważa się ujęcie Ukrzyżowanego $\mathrm{w}$ sposób szczególnie ekspresyjny, a podobieństwo formalne niektórych przedstawień ,,potwierdza kult zakonu dla ustalonego typu Ukrzyżowania stanowiącego, być może, replikę nieustalonego krucyfiksu cudownego"14. Z cech, które przywołuje Zofia Krzymulska-Fafius, jako charakterystyczne dla tych krucyfiksów, w omawianym przedstawieniu również odnajdujemy pewne elementy: głowa Chrystusa ciężko opada na prawy bok, a ciało zwisa „na ukośnie wzniesionych rękach"15.

${ }^{11}$ Święta Brygida nigdy nie złożyła profesji zakonnej, J. Swastek, Św. Brygida Szwedzka i Zakon Najświętszego Zbawiciela ze szczególnym uwzględnieniem klasztorów na ziemiach polskich, Lublin 1986, t. 1, s. 89.

${ }^{12}$ Revelationes extravagantes, rozdz. 75, cyt za: P. Giovetti, Brygida Szwedzka. Święta Europej$k a$, thum. W. Misztal, Kielce 2006, s. 46.

${ }^{13}$ Katalog Zabytków Sztuki w Polsce obrazu tego nie wykazuje, zob. t. 1: Województwo krakowskie, red. J. Szablowski, z. 12: Powiat olkuski, Warszawa 1953, s. 7-10.

${ }^{14}$ Z. Krzymulska-Fafius, Rola zakonów $w$ rozwoju rzeźby zachodniopomorskiej $w$ okresie od połowy XIV do połowy XV wieku, w: Sztuka około 1400, red. T. Hrankowska, t. 1, Warszawa 1996, s. $274,277$.

${ }^{15}$ Z. Krzymulska-Fafius, Kilka zachodniopomorskich rzeźb po-premonstrateńskich. Przyczynek do badań sztuki pobrzeża Battyku II połowy XIV wieku, ,Rocznik Muzeum Narodowego w Warszawie", 36 (1992) s. 246. 
W tym środowisku zakonnym często powstawały przedstawienia ukrzyżowania Chrystusa na Drzewie Życia ${ }^{16}$, które jest tworem chrześcijańskiej mistyki: „Belki krzyża ożyły, ponieważ zroszone zostały krwią Chrystusa, wypuściły pędy i liście" ${ }^{17}$. Drzewo Życia ${ }^{18}$ niesie treści związane z odkupieniem ${ }^{19}$, jest prefiguracją zbawienia ${ }^{20}$, znakiem ,zwycięstwa, które przynosi życie i nim obdarza”" ${ }^{21}$. Według nauki św. Tomasza z Akwinu i św. Augustyna „owoców Drzewa życia należało używać w przypadku, gdy zawiodły ludzkie środki, gdyż tylko one mogły całkowicie odnowić człowieka i go wzmocnić" 22 . W siedemnastowiecznym modlitewniku norbertanki ze Zwierzyńca, Krystyny Szembekówny, znajdujemy medytacje, w których dziękuje „Synowi Bożemu za Wcielenie, śmierć i otworzenie bram nieba"23. Norbertanki dziękują również za Eucharystię, która doprowadza „do doskonałej miłości i utrzymuje nasze zjednoczenie z Chrystusem”24.

Podstawą duchowości premonstratensów jest kult Męki Pańskiej, ale i aktywność duszpasterska ${ }^{25}$. W omawianym obrazie drzewo zakwitło kwiatami, w których umieszczone zostały półpostacie świętych norbertańskich. Zachowują się w różny sposób, również taki, jakby wprost kierowali się ku odbiorcy ${ }^{26}$, zawsze jednak zachowując konwencję obowiązującą w tamtym czasie, że mają ,przemawiać do wiernych możliwie dobitnie, ale w żadnym razie nie powinny się do nich zniżać”27.

W literaturze zwraca się uwagę, że już od XVII wieku szczególnie dbano

${ }^{16} \mathrm{Z}$ początku XVIII w. pochodzi również obraz Drzewo genealogiczne zakonu św. Norberta, w klasztorze norbertanek w Krakowie, który jest niewątpliwie powtórzeniem interesującego mnie przedstawienia. Wyraźną różnicę stanowi większa w nim liczba świętych (il. 9). Katalog Zabytków Sztuki w Polsce, t. 4, cz. 7, (seria nowa), Miasto Kraków, Zwierzyniec, Nowy Świat, red. A. Bochnk, J. Samek, Warszawa 1995.

${ }^{17} \mathrm{~S}$. Michalczuk, Ukrzyżowanie na palmie jako nowy, nieznany typ krucyfiksu barokowego, „Biuletyn Historii Sztuki”, 25 (1967) s. 25.

${ }^{18} \mathrm{O}$ wczesnych przykładach przedstawień polskich z kręgów zakonnych: Z. Świechowski, Drzewo Życia w monumentalnej rzébie romańskiej Polski, „Wrocławskie Towarzystwo Naukowe, Rozprawy Komisji Historii Sztuki”, 1 (1957) s. 113-118.

${ }^{19}$ I. Błaszczyk, Treści ideowe motywu drzewa w polskiej sztuce około roku 1400, w: Sztuka około 1400, red. T. Hrankowska, t. 2, Warszawa 1995, s. 228.

${ }^{20}$ T. Dobrzeniecki, Legenda o Secie i Drzewie Życia w sztuce średniowiecznej, „Rocznik Muzeum Narodowego w Warszawie", 10 (1966) s. 186.

${ }^{21}$ D. Forstner, Świat symboliki chrześcijańskiej, przekł. W. Zakrzewska, P. Pachciarek, R. Turzyński, Warszawa 1990, s. 155.

${ }^{22}$ Tamże, s. 153.

${ }^{23}$ A. Dygat, A. Rybak, Odrodzenie klasztoru zwierzynieckiego za Doroty Kątskiej (1591-1643), „Nasza Przeszłość” (dalej: NP), 47 (1977) s. 200.

${ }^{24}$ D.B. Goldstrom, Duchowość norbertańska duchowościa eucharystyczna, Kraków 1991, s. 5, 7.

${ }^{25}$ J. Rajman, Przyczynki do zagadnienia duchowości zakonu św. Norberta w Polsce, NP, 97 (2002) s. 5.

${ }^{26}$ Co nie było zasadą, gdyż są i takie wyobrażenia, w których święci ukazani zostali w usztywnionych pozach, np. na ornacie z drzewem zakonu dominikańskiego (il. 10).

${ }^{27}$ A. Hauser, Społeczna historia sztuki i literatury, przeł. J. Ruszczycówna, Warszawa 1974, s. 351 . 
o kult świętych zakonu, co wiązane jest z nową świadomością tożsamości, jaką zdobywały wówczas wspólnoty monastyczne ${ }^{28}$. Bóg daje „zakonom patronów Świętych, ktorzyby w potrzebach ich swoią przyczyną za nimi się wstawiali"29. $\mathrm{W}$ „kościele premonstratensów raz w tygodniu była msza święta ku czci patrona kościoła" ${ }^{30}$, „a żywe związki polskich premonstratensów z Zachodem [...] zaowocowały zarówno recepcją kultów świętych i gromadzeniem cennych relikwii" ${ }^{31}$. Z pochodzącego z XVII wieku listu dedykacyjnego ks. Macieja z Hebdowa do ksieni Doroty Kątskiej, zamieszczonego w jego polskim tłumaczeniu żywotów świętych i błogosławionych norbertańskich, dowiadujemy się, że kult ten miał dwa cele: chwałę Bożą i pożytek norbertanek, aby te „świętych swoich chwaliły i naśladować mogły"32. W czym naśladować? O tym mówi interesujący nas obraz.

Jedni święci mają oczy wzniesione i spoglądają na Chrystusa Ukrzyżowanego. W taki sposób w sztuce unaoczniano ich łączność z niebem, widzimy ich bowiem „kontemplujących to, czego ludzie nie widzą" ${ }^{33}$. Antoni Daniel Kraszewski, norbertanin żyjący w XVIII wieku, autor księgi o świętych swojego zakonu, nazywa rzecz precyzyjnie: „Zakonnik, który pilnie y nabożnie w Męce Pańskiey przegląda się, wszystko pożyteczne y potrzebne obficie tam znayduie, ani potrzeba, żeby czego lepszego gdzie indziey szukał" ${ }^{34}$. W omawianym obrazie oczy niektórych świętych skierowane są na św. Norberta. W taki sposób została pla-

${ }^{28}$ K.S. Frank, Renesans wptywów monastycyzmu w Europie Środkowej po reformacji, w: A. Solignac i in., Monastycyzm. Historia i duchowość, thum. D. Stadnicka-Apostoł, Kraków 2002, s. 140

${ }^{29}$ A.D. Kraszewski, Życie Świętych i w nadziei Świątobliwości zeszłych Stug Boskich Zakonu Premonstrateńskiego, cz. 1, Warszawa 1752, s. 288 - do pomocy świętych uciekamy, „ponieważ w Pana Boga są w łasce, prosimy o to aby przyczynę za nami czynili, y czego nam trzeba uprosili. Przeto [...] kiedy kto przed Obrazem ktorego Swiętego mowi Pacierze, tedy niechay tak rozumie, iż go prosi o to, aby się z nim modlił, y to mu uprosił co się w Pacierzu zamyka: a iżby też iego tłumaczem był, y zań Pana Boga prosił. Bo nauczył nas święty Jan w Objawieniu swoim, że Święci za ludzie się modlą". Ta kwestia w okresie potrydenckim była ściśle uregulowana. W katechizmie z tego czasu, w rozdziale pt: Komu się modlić mamy, czytamy: „nie iednakim obyczaiem Boga y Świętych wzywamy. Albowiem prosimy Pana Boga iżby on sam darow swoich nam użyczył, albo nas od złych przygod wyzwolił: Ale Swiętych, ponieważ w Pana Boga są w łasce, prosimy o to aby przyczynę za nami czynili, y czego nam trzeba uprosili. Przeto używamy dwoiakiego y roznego obyczaiu w modleniu. Bo Panu Bogu tak właśnie mowimy, Zmiłuj się nad nami. Wysłuchay nas. A do świętych tak: Modl się za nami. Aczkolwiek możemy też inszym sposobem prosić Swiętych, aby się zmiłowali nad nami: bo są bardzo miłosierni. Dla tego możemy ich prosić, aby nędzą naszą poruszeni, ratowali nas u Boga łaską y przyczyną swoią”, W. Kuczborski, Katechizm, albo Nauka wiary y pobożności krześcijańskiey wedlug uchwaty s. Tridentskiego Concilium przez uczone a bogobojne ludzie zebrana y spisana, Kraków 1568, s. 365.

${ }^{30}$ Rajman, Przyczynki do zagadnienia duchowości, s. 7.

${ }^{31}$ Tamże, s. 17.

32 J. Gwioździk, Księga żywotów świętych norbertańskich ksieni Doroty Kątskiej w zbiorach biblioteki uniwersyteckiej we Lwowie, http//:www.anthropos.org.ua, s. 5 [dostęp: 28. 10. 2013].

${ }^{33}$ É. Mâle, L'art religieux après le Concile de Trente, Paris 1932, s. 103.

${ }^{34}$ Kraszewski, Życie Świętych, cz. 1, s. 200. 
stycznie wyrażona idea, że zakonnik „te tylko dni może liczyć, w ktore własną wolą przełamał, y one bez przestąpienia naymnieyszego Reguły przepędził" $3{ }^{35}$. Spośród świętych, którzy patrzą na widza możemy wyróżnić takich, którzy wykonują gesty kierujące nasze spojrzenie na Jezusa ${ }^{36}$. Potwierdzając swoim autorytetem, ponaglają widzów do kontaktu z Chrystusem. Odgrywają więc rolę, którą w sztuce nazwa się introdutio ${ }^{37}$. Inni trzymają atrybut, jako świadectwo swojej świętości. Antoni Daniel Kraszewski przywołuje słowa św. Izydora: „Dobrze ten dwoiako mowi, kto dobrze żyie, i dobrze naucza, ale źle dwa razy mowi, kto źle żyie y źle naucza" 38 . Gdy przedstawienia takie mnisi znajdowali w miejscach odosobnionych, mieli szansę w spokoju pogłębić powyższe treści o te, które umożliwiała im znajomość żywotów świętych swojego zakonu. Na przykład, w biografii św. Josepha Hermana, którego rozpoznajemy w omawianym obrazie, czytamy, że wykonując obowiązki zakonne mało miał czasu na modlitwę, wówczas Maryja przypomniała mu, że „nic tak z powinności do ciebie nie należy, iako to, żebyś z wielką miłością służył braciom swoim" ${ }^{39}$.

Widzimy więc, że w przypadku tego obrazu przedstawieni święci nie stanowią galerii portretów świętych swojego zakonu, ale są to konkretni ludzie o indywidualnej historii życia, odnoszący się do aktualnie żyjących norbertanek, które podjęły tę samą regułę zakonną. Św. Brygida założycielka zakonu Najświętszego Zbawiciela zapisała, że z trzech rzeczy, dzięki którym człowiek może uniknąć grzechu, obok pokuty i postanowienia więcej grzechów nie popełniać jest ,poprawić się w życiu swoim według rad onych, ktorych widzi że wzgardzili światem" ${ }^{40}$. Podobnie jest w środowisku premonstratensów. Kraszewski ujął to w następujący sposób: „Swiętych przykłady do wzgardy świata nas wzbudzają" ${ }^{41}$, a kontynuując myśl pisze o św. Alderyku: ,poszedł do Szlachetnych Panien Zakonu Premonstrateńskiego na wesołej równinie położonego [...] świątobliwością tam kwitnącą zachęcony. Gdzie do zaszczepionego tego Ręką Boską Raiu, on się też, iako nowy szczep przyłączył ${ }^{42}$.

W omawianym obrazie konary, na których święci są przedstawieni oznaczają tylko część większej całości - drzewa, które „organicznie bierze udział w chwale kwiatu, którym jest Chrystus" ${ }^{43}$. Można więc uznać to przedstawienie za plastyczne wyobrażenie idei, że zbawcza męka Chrystusa na krzyżu stała się przyczyną

${ }^{35}$ Tamże, s. 218.

${ }^{36}$ Mâle, L'art religieux, s. 103.

${ }^{37}$ H. Benesz, Daniel and King Cyrus in Front of Baal. A late Rudolfine and late humanist painting by Bartholomäus Strobel from the collections of the National Museum in Warsaw, „Bulletin du Musée National de Varsovie", 22 (1991) no 3, s. 349; J. Tylicki, Bartomiej Strobel malarz epoki wojny trzydziestoletniej, t. 1, Toruń 2000, s. 149.

${ }^{38}$ Kraszewski, Życie Świętych, cz. 1, s. 230.

${ }^{39}$ Tamże, s. 161.

${ }^{40}$ Poczyna się xięa III Objawienia niebieskiego S. Brygitty, ze Szwecyey, w: Skarby Niebieskich Taiemnic..., rozdz. 12, s. 178.

${ }^{41}$ Kraszewski, Życie Świętych, cz. 1, s. 308.

${ }^{42}$ Tamże, s. 59.

${ }^{43}$ Ladner, Medieval and Modern Understanding, s. 250-251. 
doskonałości świętych norbertańskich, ich doczesnego raju zobrazowanego przez bujne pędy drzewa. Ale drzewo symbolizuje organiczny wzrost od korzeni do szczytu, a nie odwrotnie ${ }^{44}$, dlatego należy uważać, iż unaoczniono tu fakt, że święci łącząc się z cierpieniem Chrystusa, doskonalili się żyjąc według reguły zakonnej, aby następnie móc stanowić wzór dla innych. W ten sposób wypełniali nakaz Chrystusa skierowany do uczniów: ,aby wprzód poieli Jego cnoty przez naśladowanie: uczcie się ode mnie, a dopiero opowiadajcie Ewangelię"45. Takie rozumienie potwierdza wcześniej dokonane ustalenie, że przedstawienie genealogicznego drzewa zakonnego ukazuje, rzeczywisty kontakt w znaczeniu kontynuacji, której podstawą jest reguła zakonna, której codzienne wypełnianie daje świętość; przecież kwiaty, w których są ukazani święci są nadzieją na owoce ${ }^{46}$.

W środowisku premonstratensów omawiany obraz miał budzić przekonanie w zakonniku, że zachowując regułę zakonną ${ }^{47}$ oraz oddając cześć Eucharystii, może osiągnąć świętość, a święci zakonu, którzy już spełnili to zalecenie, są najlepszymi nauczycielami na drodze doskonalenia duchowego ${ }^{48}$.

Tego typu przedstawienia były popularne również w innych środowiskach zakonnych. Przy wszystkich różnicach, wspólna im była funkcja, jaką spełniały. Pozostawały informacją o podstawach ich drogi duchowej, ale też zapewnieniem o jej skuteczności w doprowadzeniu do Nieba.

${ }^{44}$ Tamże.

${ }^{45}$ Kraszewski, Życie Świętych, cz. 1, s. 68.

${ }^{46}$ M. Lurker, Stownik obrazów i symboli biblijnych, tłum. K. Romaniuk, Poznań 1989, s. 106.

${ }^{47}$ Reguła to podstawa życia zakonnego, dlatego w omawianym obrazie zakonodawca, św. Norbert jest ukazany w bezpośrednim sąsiedztwie zabudowań klasztornych - miejsca, w którym jego reguła jest na co dzień realizowana. Widzimy sylwetkę kościoła oraz mur okalający klasztor z bramą wjazdową o masywnej sylwetce zbudowanej na planie owalnym. W polskim malarstwie barokowym często wprowadzano elementy aktualizujące. W związku z tym można się spodziewać, że ukazano tu fragment klasztoru, do którego obraz był przeznaczony. Nie jest to architektura konwentu w Imbramowicach ukazująca obecny stan, projektu Kacpra Bażanki. Niestety jak utrzymują autorzy zajmujący się historią tego obiektu obecnie nie dysponujemy źródłami ikonograficznymi, które umożliwiałyby stwierdzenie, czy mamy tu do czynienia ze stanem zespołu przed przebudową Kacpra Bażanki, L. Sobol, Kultura klasztoru ss. norbertanek w Imbramowicach 1229-2004, Kraków 2005, s. 24, 86.

${ }^{48}$ „Wśród wzorców hagiograficznych okresu staropolskiego dominował ideał doskonałości zakonnej, propagujący określone postawy religijne i moralne oraz kształtujący osobowość i przynoszący gotowe wzorce ascezy, przydatne zwłaszcza w nowicjacie i w czasie renowacji”, U. Borkowska, Hagiografia polska (wiek XVI-XVIII), w: Dzieje teologii katolickiej w Polsce, red. M. Rechowicz, t. 2, cz. 2, Lublin 1975, s. 490. 


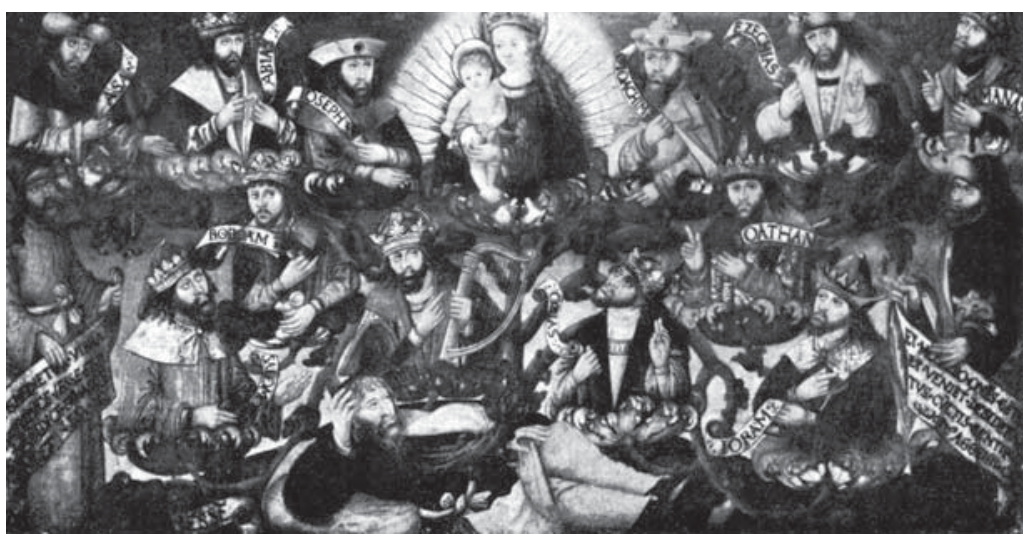

Fot. 1. Drzewo Jessego, kościół w Gostyniu, predella ołtarza z 1546, za: Katalog Zabytków Sztuki w Polsce, t. V, woj. poznańskie, z. 4 pow. gostyński, red. T. Ruszczyńska, A. Sławska, Warszawa 1961, il. 82.

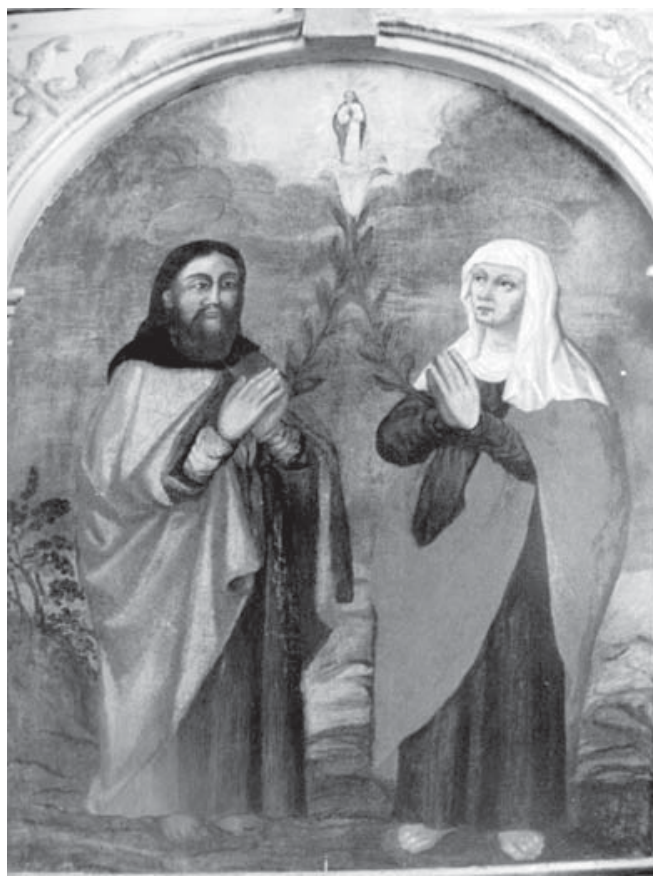

Fot. 2. Arbor Virginis, kościół parafialny w Wielogłowach. 


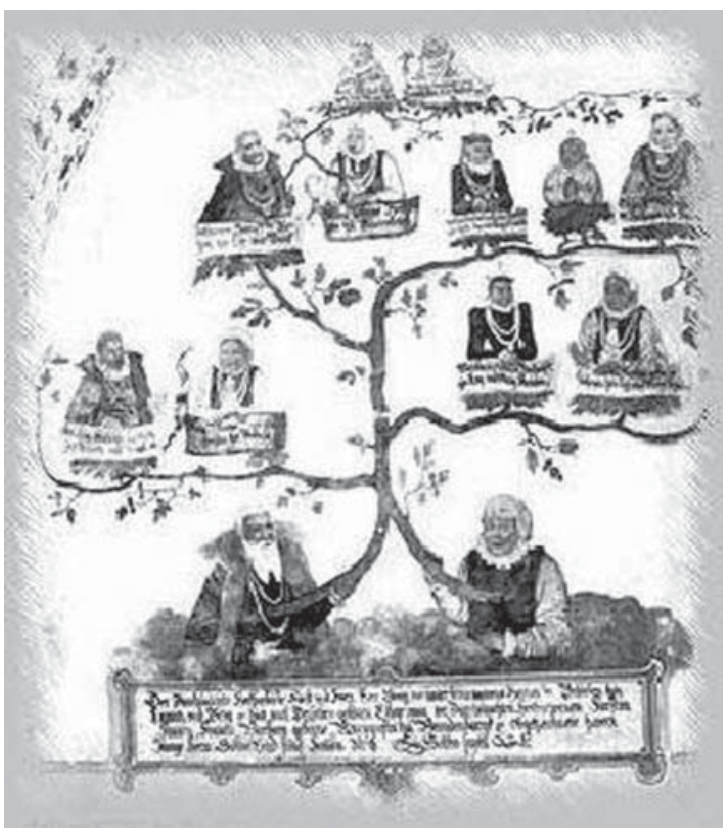

Fot. 3. Drzewo genealogiczne Jerzego II na zamku w Brzegu, za: Portret na Śląsku XVI-XVIII, katalog wystawy, red. E. Houszka, Wrocław 1984, s. 12.

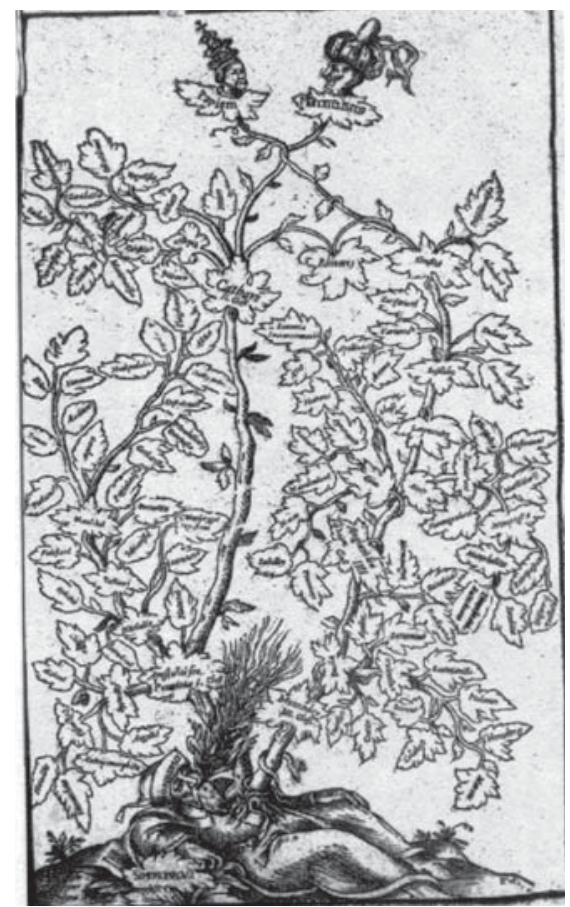

Fot. 4. Drzewo genealogiczne herezji, drzeworyt, Daniel Cramer, Apocalipsis, Szczecin 1618, za: M. Wisłocki, Treści polemiczne w ewnagelickiej sztuce Pomorza XBVI i XVII wieku, w: Sztuka i dialog wtyznań w XVI i XVII wieku, red. J. Harasimowicz, Warszawa 2000, il. 4, s. 151. 


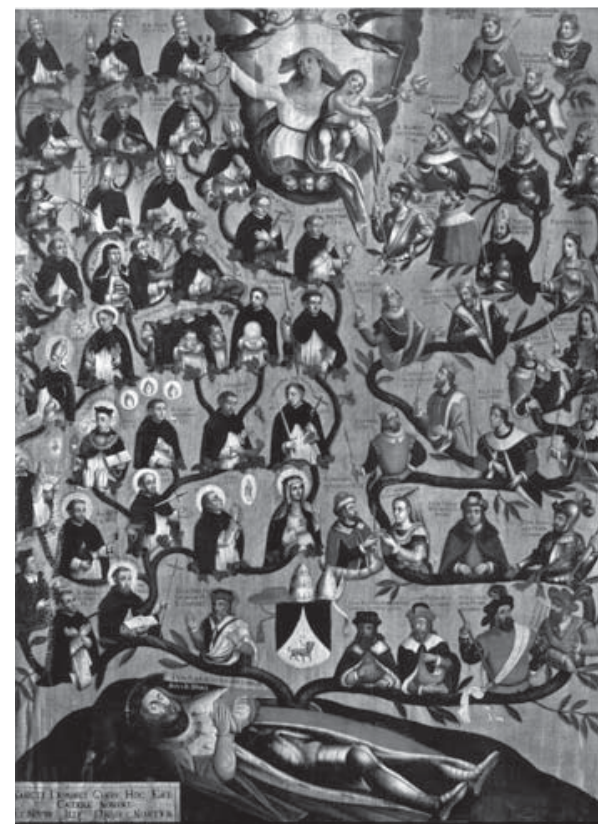

Fot. 5. Barokowe drzewo genealogiczne rodziny Guzmanów i zakonne dominikanów i dominikanek z 1608 r. w klasztorze Dominikanów w Krakowie, olej na płótnie naklejony na deskę, autor nieznany, za: M. Grochowski, J. Marecki, Zakony w Polsce, Warszawa 2009, s. 98.

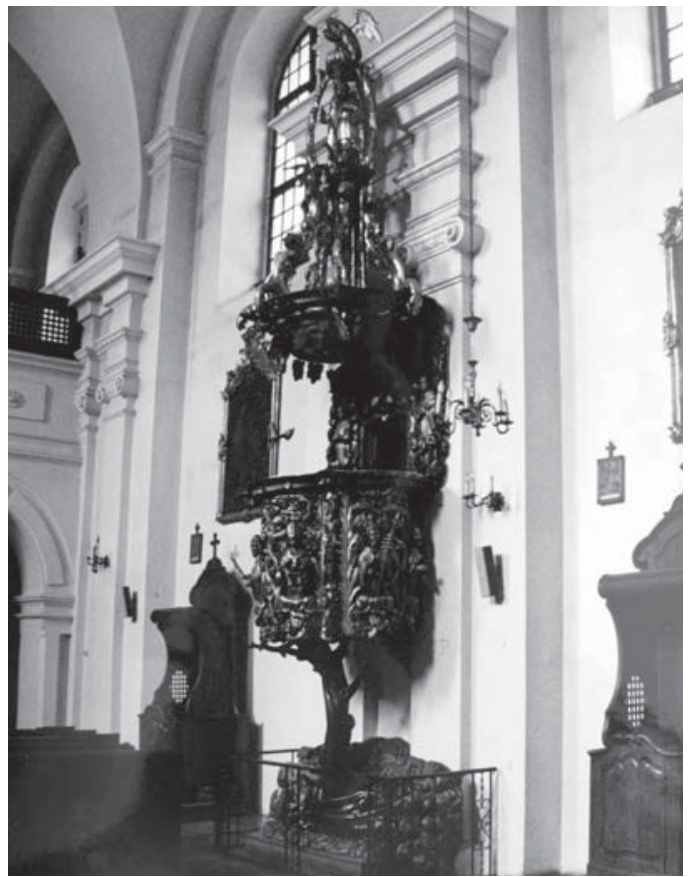

Fot. 6. Drzewo genealogiczne zakonu benedyktynów, dawny kościół benedyktynek w Sandomierzu, 1694-1695. 


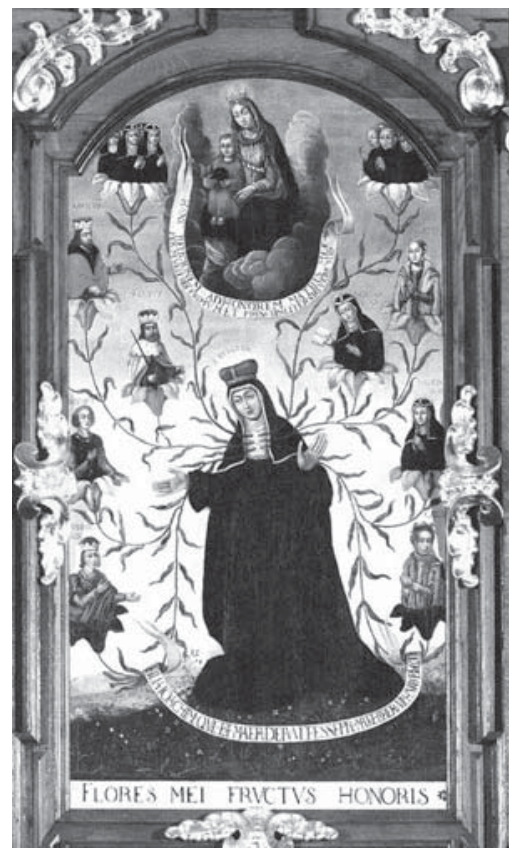

Fot. 7. Drzewo genealogiczne św. Brygidy. Stalle w prezbiterium kościoła pw. Matki Boskiej Zwycięskiej w Lublinie.

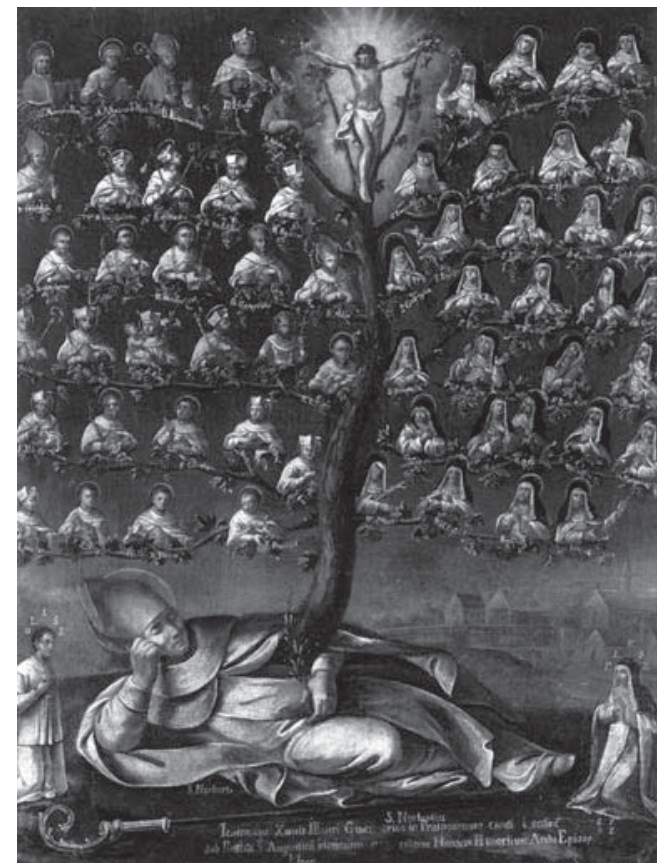

Fot. 8. Drzewo genealogiczne zakonu św. Norberta, klasztor w Imbramowicach. 


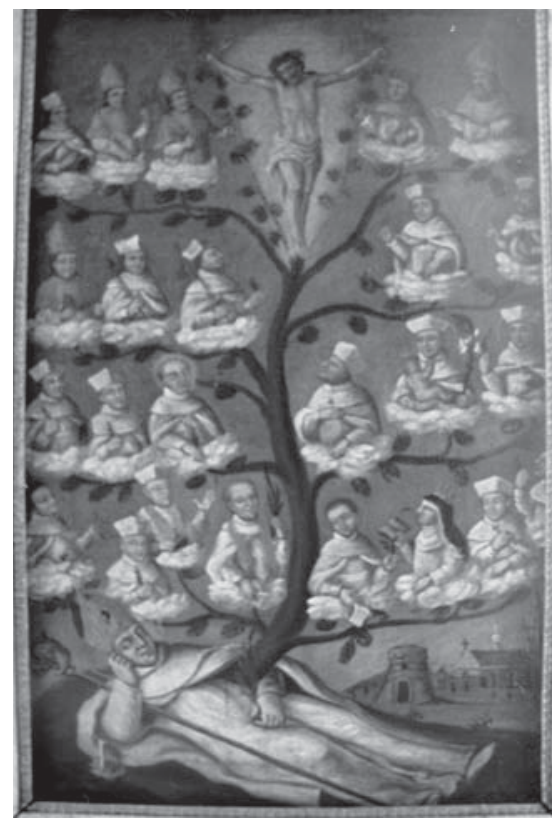

Fot. 9. Obraz z pocz. XVIII w. znajdujący się w chórze klasztoru norbertanek w Krakowie, przedstawiący drzewo zakonne norbertan i norbertanek, za: M. Grochowski, J. Marecki, Zakony w Polsce, Warszawa 2009, s. 115.

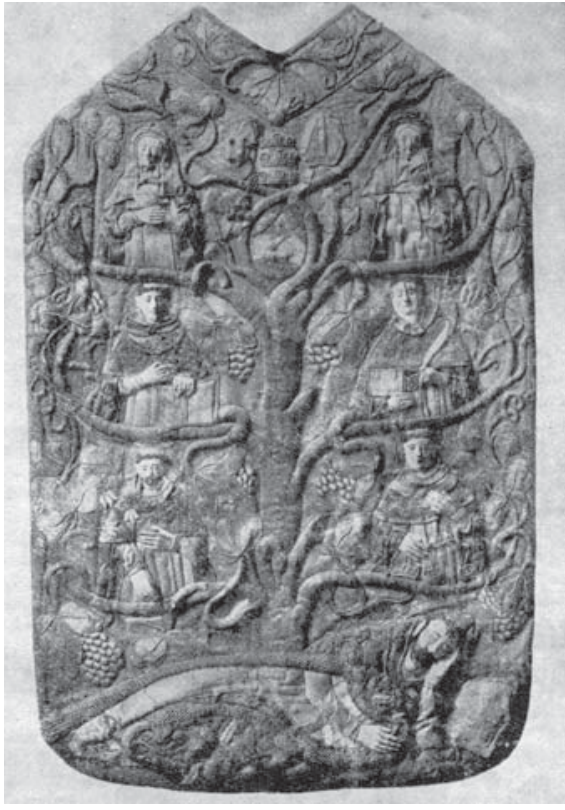

Fot. 10. Ornat z drzewem zakonu dominikanów z kościoła dominikanów w Krakowie, za: J. Samek, Problem aktualności tematu „Drzewo Jessego” w sztuce polskiej wieku siedemnastego, „Zeszyty Naukowe Uniwersytetu Jagiellońskiego, t. 339, „Prace z Historii Sztuki”, z. 11, 1973, il. 14. 


\title{
ROLE OF GENEALOGICAL TREE REPRESENTATIONS FOR PREMONSTRATENSIANS
}

\begin{abstract}
Summary
The commonly known representation of Tree of Jesse, as inspired by the words „And the wand will come out of the root of Jesse and a flower will grow out of from its root" (Isaiah 11:1), proves the interpersonal relationships with Jesus and His messianic prophecy - by indicating on David. But since the earliest times this theme has been explored in the secular art because branching limbs with characters of descendants, growing from the parents' chest, clearly illustrate the relations resulting from successions of generations within the family framework.

This kind of representations was also popular in orders. At that time they not only provided the information on the background of spiritual path but also the assurance of its effectiveness on the way to reach Heaven. The images of the Order of Canons Regular of Prémontré, also known as the Premonstratensians, elaborated upon in this paper, was to make canons regular believe that abiding by the rules and laws made by the Order and praising the Eucharist, canons regular may master themselves to perfection and the saints of the order, who had already successfully fulfilled this recommendation, were the best teachers on the path of spiritual progress.
\end{abstract}

Translated by Monika Zielińska-Choina 